\title{
Change of the Name Alteromonas marinopraesens (ZoBell and Upham) Baumann et al. to Altero- monas haloplanktis (ZoBell and Upham) comb. nov. and Assignment of Strain ATCC 23821 (Pseudomonas enalia) and Strain c-A1 of De Voe and Oginsky to This Species
}

\author{
JOHN L. REICHELT ${ }^{1}$ and PAUL BAUMANN ${ }^{1}$ \\ Department of Microbiology, University of Hawaii, Honolulu, Hawaii 96822
}

\begin{abstract}
For reasons discussed, the name Alteromonas marinopraesens (ZoBell and Upham) Baumann et al. is changed to Alteromonas haloplanktis (ZoBell and Upham) comb. nov. In addition to the 17 strains placed in this species by Baumann et al,, two other strains, c-A1 of De Voe and Oginsky and ATCC 23821 (the latter previously identified as belonging to Pseudomonas enalia ZoBell and Upham), were assigned to this species on the basis of the results of an extensive phenotypic characterization of these strains and the guanine plus cytosine contents (moles/100 $\mathrm{ml}$ ) of their deoxyribonucleic acids.
\end{abstract}

In a taxonomic study of nonfermentative, gram-negative, marine bacteria, the genus Alteromonas was proposed for species of strictly aerobic, polarly flagellated rods which had guanine plus cytosine $(G+C)$ contents in their deoxyribonucleic acids (DNAs) of 41.8 to 49.3 $\mathrm{mol} / 100 \mathrm{ml}$ (2). One species of this genus consisted of 17 strains, one of which had been previously designated Vibrio haloplanktis ZoBell and Upham (American Type Culture Collection [ATCC] 14393; strain 215 of Baumann et al. [2]) and the other had been designated $V$. marinopraesens ZoBell and Upham (ATCC 19648; strain 216). Since it was erroneously thought (2) that both of these strains were the original isolates of ZoBell and Upham (14), and hence type strains of these species, the two names were declared synonyms. Because no other type strains were placed in this species, the name Alteromonas marinopraesens was proposed for it, the specific epithet "marinopraesens" having been arbitrarily chosen over "haloplanktis." The error of this choice has been pointed out by E. F. Lessel

\footnotetext{
${ }^{1}$ Present address: Department of Bacteriology University of California, Davis, Calif. 95616.
}

(personal communication), who noted that ATCC 19648 was not an original strain of ZoBell and Upham but only a later isolate of R. $\mathrm{N}$. Johnson which was identified as $V$. marinopraesens. On the other hand, strain ATCC 14393 (strain 215) is an isolate of ZoBell, and it is designated here as the type strain of $V$. haloplanktis. This strain has the characters of $V$. haloplanktis as originally described by ZoBell and Upham (14). Therefore, the correct name of the species previously characterized by Baumann et al. (2) is Alteromonas haloplanktis (ZoBell and Upham) comb. nov., not Alteromonas marinopraesens. It should also be noted that our previous designation (2) of $V$. haloplanktis and $V$. marinopraesens as synonyms was not valid. Instead, our work (2) merely indicated that ATCC 19648 (strain 216), which had been deposited in the ATCC under the designation $V$. marinopraesens, belonged in the species $A$. haloplanktis.

$A$. haloplanktis includes strain B-16 of MacLeod, which has been the object of extensive studies aimed at elucidating the nature of marine bacteria $(9,10)$. Much of the work of MacLeod and his collaborators has focused on the structure and function of the 
cell wall of strain B-16 (7, 8). Another marine bacterium which has been investigated with respect to its cell wall but which was not characterized in our previous work is strain c-A 1 of De Voe and Oginsky $(5,6)$. Since the number of studies dealing with cell walls of marine bacteria are few, we performed a taxonomic characterization of this strain in order to determine its relationship to the isolate of MacLeod.

An additional organism characterized in the study reported here is strain ATCC 23821 . This gram-negative, marine bacterium was isolated from an oyster by Colwell and Sparks (4) and identified as Pseudomonas enalia ZoBell and Upham. The basis for this assignment is not clear since the initial description of $P$. enalia (14) was not adequate to permit its recognition and since no type or neotype strain was available for comparison. Furthermore, strain ATCC 23821 and the original description of $P$. enalia differ in that the latter was described as having several polar flagella at each pole (14) whereas strain ATCC 23821 had a single polar flagellum at one pole (4).

Strains 119 to 132 , inclusive, and 214 to 216 , inclusive, have been previously characterized (2) and are assigned to A. haloplanktis. The sources of strain 119 to 132 have been described (2). Strains 214,215 , and 216 were obtained from the ATCC under the following numbers: 19855 (B-16 of MacLeod), 14393, and 19648, respectively. Strain c-A 1 was received from I. W. De Voe, and $P$. enalia ATCC 23821 was obtained from the ATCC.

The methods used for the characterization of strains c-Al and ATCC 23821 have been previously described $(2,3,13)$.

Strains C-A l and ATCC 23821 as well as the previously characterized strains of $A$. haloplanktis (2) were oxidase-positive, straight rods which were motile by means of a single polar flagellum (Fig. 1). The $\mathrm{G}+\mathrm{C}$ content (moles/100 ml) in the DNA of strain ATCC 23821 was 41.4 as determined by thermal denaturation (12); the $\mathrm{G}+\mathrm{C}$ content of strain c-A 1 was 41.2 moles $/ 100 \mathrm{ml} \mathrm{(5).} \mathrm{These} \mathrm{values}$ are similar to the previous $\mathrm{G}+\mathrm{C}$ determinations of six characterized strains of $A$. haloplanktis (including strain 215, the type strain, and B-16) which ranged from 41.8 to 44.4 moles/ $100 \mathrm{ml}$ (2). Neither strain denitrified, reduced nitrate to nitrite, was capable of accumulating poly- $\beta$ hydroxybutyric acid as an intracellular reserve product, nor was able to grow at 4 or $35 \mathrm{C}$. Both strains were able to grow at $30 \mathrm{C}$. The nutritional properties of strains c-A 1 and ATCC

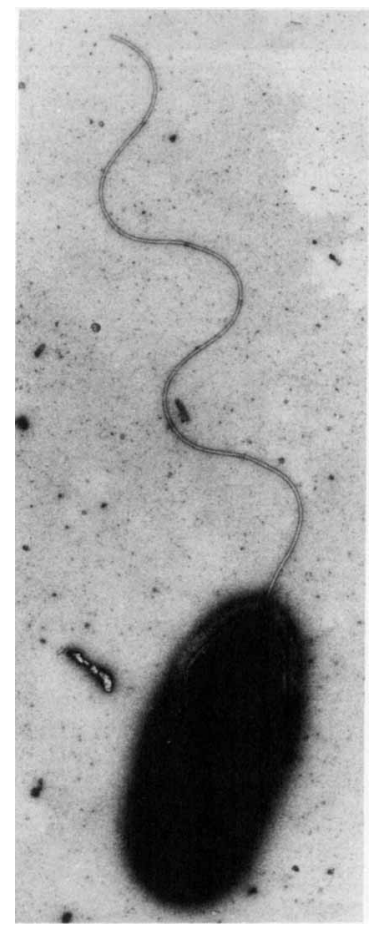

FIG. 1. Electron micrograph of Alteromonas haloplanktis, strain 215. Negatively stained (1). $\times 16,000$.

23821 are presented in Table 1. For comparative purposes, the nutritional properties of strain 215 and 16 other strains of this species (2) are also included in this table. As seen from Table 1 , strain $\mathrm{c}-\mathrm{A} 1$ and ATCC 23821 were similar in their nutritional properties to $A$. haloplanktis. The sole positive trait of strain ATCC 23821 which distinguished it from the other strains was its ability to utilize $n$-butanol. Only a few compounds which served as sole sources of carbon and energy for some of the previously characterized members of $A$. haloplanktis were not utilized by either strain c-A 1 or ATCC 23821. These data, together with the phenotypic data for the strains of $A$. haloplanktis and $A$. macleodii previously studied by Baumann et al. (2), were submitted to a numerical analysis; the results are presented in Fig. 2. All of the strains of $A$. haloplanktis were linked at a similarity value of $80 \%$, and the resulting cluster joined the 21 strains of $A$. macleodii at a similarity value of $72 \%$.

On the basis of their phenotypes and the $\mathrm{G}+$ C contents (moles/100 ml), strains c-Al and ATCC 23821 are assigned to $A$. haloplanktis. This species, therefore, contains two strains 
TABLE 1. Comparison of the nutritional properties of strains c-Al and ATCC 23821 with the previously characterized strains of $A$. haloplanktis ${ }^{a}$

\begin{tabular}{|c|c|c|c|c|c|c|c|c|c|}
\hline $\begin{array}{c}\text { Nutritional } \\
\text { property }\end{array}$ & $\begin{array}{l}\text { c-Al } \\
(1)^{b}\end{array}$ & $\begin{array}{c}\text { ATCC } \\
23821 \\
(1)\end{array}$ & $\begin{array}{c}215 \text { (type } \\
\text { strain) } \\
(1)\end{array}$ & $\begin{array}{c}\text { A. halo- } \\
\text { planktis } \\
(16)\end{array}$ & $\begin{array}{l}\text { Nutritional } \\
\text { property }\end{array}$ & $\begin{array}{c}\mathrm{c}-\mathrm{Al} \\
(1)\end{array}$ & $\begin{array}{c}\text { ATCC } \\
23821 \\
(1)\end{array}$ & $\begin{array}{c}215 \text { (type } \\
\text { strain) } \\
(1)\end{array}$ & $\begin{array}{l}\text { A. halo- } \\
\text { planktis } \\
\quad(16)\end{array}$ \\
\hline Amylase & + & - & - & 1 & Caprate & + & + & + & + \\
\hline Gelatinase & + & + & + & + & Succinate & + & + & + & + \\
\hline Lipase & + & + & + & + & Fumarate & + & + & + & + \\
\hline Chitinase & + & + & - & 14 & $\begin{array}{l}\text { DL- } \beta \text {-hydroxy- } \\
\text { butyrate }\end{array}$ & + & + & - & 7 \\
\hline L-arabinose & + & - & - & 11 & Citrate & - & - & - & 15 \\
\hline D-glucose & + & + & + & + & Pyruvate & + & + & + & + \\
\hline D-fructose & - & - & + & 10 & Aconitate & - & - & - & 15 \\
\hline D-mannose & - & - & - & 15 & Ethanol & + & + & - & + \\
\hline Sucrose & + & + & - & 15 & $n$-Propanol & + & + & - & 13 \\
\hline Trehalose & + & + & - & 13 & $n$-Butanol & - & + & - & - \\
\hline Maltose & + & + & + & + & Gly cine & + & - & + & 13 \\
\hline$N$-acetyl- & & & & & L- $\alpha$-alanine & + & + & + & + \\
\hline glucosamine & + & + & - & 15 & L-serine & + & + & + & + \\
\hline Acetate & + & + & + & + & L-threonine & + & - & - & 1 \\
\hline Propionate & + & + & + & + & L-leucine & - & + & + & 5 \\
\hline \multirow[t]{2}{*}{ Butyrate } & - & + & - & 6 & & & & & \\
\hline & & & & & L-glutamate & + & + & + & 13 \\
\hline Isobutyrate & + & - & - & 14 & L-citrulline & - & - & + & 1 \\
\hline Valerate & + & + & + & 10 & L-proline & + & + & + & 8 \\
\hline Isovalerate & - & + & - & 1 & L-tyrosine & + & + & + & 14 \\
\hline Caprylate & - & - & + & 13 & & & & & \\
\hline Pelargonate & - & - & + & 14 & & & & & \\
\hline
\end{tabular}

${ }^{a}$ Symbols: +, all strains positive; -, all strains negative. Numbers indicate number of positive strains; boldface numbers indicate that the number represents $80 \%$ or more of the strains. For purposes of comparison, traits which were present in $80 \%$ or more of the previously characterized strains of $A$. haloplanktis and were absent in strains c-Al and ATCC 23821 were included in this table. Compounds listed by Baumann et al. (2) but not included in this table were not utilized by strains c-Al, ATCC 23821, and 215.

$b$ Numbers of strains studied indicated in parentheses.

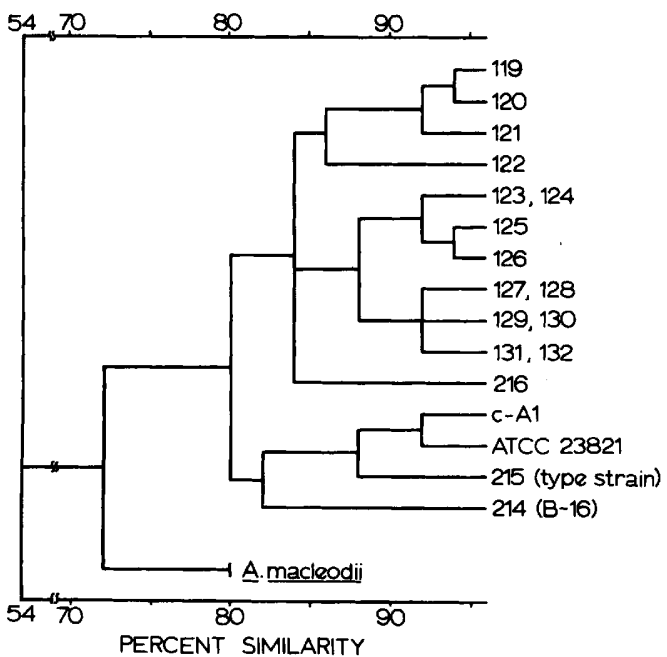

FIG. 2. Numerical analysis of strain $c-A 1$ and $A T C C$ 23821 as well as of previously characterized strains of Alteromonas haloplanktis.
(B-16 of MacLeod and c-Al of De Voe and Oginsky) which have been studied with respect to the structure of their cell walls $(5,6,7,8)$. $A$. haloplanktis appears to be a species commonly occurring in seawater, as is evident from its ready isolation from the coastal waters of Hawaii (2) and from various locations along the West Coast of North America $(4,5,11,14)$.

\section{ACKNOWLEDGMENTS}

We thank Richard D. Allen and M. Ueno for use of the electron micrograph and acknowledge the assistance of Linda Baumann and the criticisms of Rita Mynah. This investigation was supported by Public Health Service Grant FD 00520 from the Division of Environmental Health Sciences.

\section{REPRINT REQUESTS}

Address requests for reprints to: Paul Baumann, 
Department of Bacteriology, University of California, Davis, Calif. 95616.

\section{LITERATURE CITED}

1. Allen, R. D., and P. Baumann. 1971. Structure and arrangement of flagella in species of the genus Beneckea and Photobacterium fischeri. J. Bacteriol. 107:295-302.

2. Baumann, L., P. Baumann, M. Mandel, and R. D. Allen. 1972. Taxonomy of aerobic marine eubacteria. J. Bacteriol. 110:402-429.

3. Baumann, P., L. Baumann, and M. Mandel. 1971. Taxonomy of marine bacteria: the genus Beneckea. J. Bacteriol. 107:268-294.

4. Colwell, R. R., and A. K. Sparks. 1967. Properties of Pseudomonas enalia, a marine bacterium pathogenic for the invertebrate Crassostrea gigas (Thunberg). Appl. Microbiol. 15:980-986.

5. De Voe, I. W., and E. L. Oginsky. 1969. Antagonistic effect of monovalent cations in maintenance of cellular integrity of a marine bacterium. J. Bacteriol. 98:1355-1367.

6. De Voe, I. W., and E. L. Oginsky. 1969. Cation interactions and biochemical composition of the cell envelope of a marine bacterium. J. Bacteriol. 98:1368-1377.

7. Forsberg, C. W., J. W. Costerton, and R. A.
MacLeod. 1970. Separation and localization of cell wall layers of a gram-negative bacterium. J. Bacteriol. 104:1338-1353.

8. Forsberg, C. W., J. W. Costerton, and R. A. MacLeod. 1970. Quantitation, chemical characteristics, and ultrastructure of the three outer cell wall layers of a gram-negative bacterium. J. Bacteriol. 104:1354-1368.

9. MacLeod, R. A. 1965. The question of the existence of specific marine bacteria. Bacteriol. Rev. 29:9-23.

10. MacLeod, R. A. 1968. On the role of inorganic ions in the physiology of marine bacteria. Advan. Microbiol. Sea 1:95-168.

11. MacLeod, R. A., E. Onofrey, and M. E. Norris. 1954. Nutrition and metabolism of marine bacteria. 1. Survey of nutritional requirements. J. Bacteriol. 63:680-686.

12. Marmur, J., and P. Doty. 1962. Determination of the base composition of deoxyribonucleic acid from its thermal denaturation temperature. J. Mol. Biol. 5:109-118.

13. Stanier, R. Y., N. J. Palleroni, and M. Doudoroff. 1966. The aerobic pseudomonads: a taxonomic study. J. Gen. Microbiol. 43:159-271.

14. ZoBell, C. E., and H. C. Upham. 1944. A list of marine bacteria including description of sixty new species. Bull. Scrips Inst. Oceanogr. Univ. Calif. 5:239-292. 